\title{
Handmade Traditional Kiln Clay Bricks from Tamilnadu, India: Mineralogy, Temperature Effect and Mechanical Analysis
}

\author{
P. Sutharsan ${ }^{1}$, S. Dhanapandian'2, V. Venkatachalam ${ }^{3}$, T.M. Puratchi Mani ${ }^{4}$, S. Abraham Rajasekar ${ }^{5}$ \\ ${ }^{1,3,5}$ Department of Physics, Sir Theagaraya Collge, Old Washermenpet (Govt. Aided), Chennai-21, Tamilnadu, India. \\ ${ }^{2}$ Department of Physics, Annamalai University, Annamalai Nagar - 608 002, Tamilnadu, India. \\ ${ }^{4}$ Department of Physics, As-Salam College of Engineering and Technology, Thirumangalakudi, Aduthurai- 612 012, India.
}

\begin{abstract}
This work shows the changes in properties of industrial clay bricks collected from the traditional kiln situated at bank of Cauvery, Tamilnadu, India. Samples of local raw clay material already in use for the production of bricks and industrially produced fired brick materials were characterized by combined multi-analytical techniques to determine the relationships among chemical, mineralogical, textural and mechanical properties. FTIR absorption spectra of re-fired industrial clay bricks to different temperatures in air in the laboratory supply information about type of clay mineral presence, its original firing temperature and firing atmosphere. The minerals like quartz, plagioclase (albite or anorthite) and orthoclase were identified using XRD. In order to study the quality of the bricks they were submitted to mechanical analysis such as compressive strength, flexural rupture strength, water absorption, porosity and bulk density. The mechanical analysis reveals that when laboratory re-firing temperature exceeds the original firing temperature of industrial bricks, the compressive strength, flexural rupture strength and bulk density increases, whereas water absorption and porosity values decreases. The results showed that there is a drastic variation in the quality of the bricks collected from different parts of the same kiln.
\end{abstract}

KEYWORDS: Brick, Clay material, Firing temperature, Mechanical properties.

\section{INTRODUCTION}

Bricks are small rectangular ceramic blocks obtained by firing raw clay $\left(650\right.$ to $\left.1000^{\circ} \mathrm{C}\right)$ which are played a significant role in the building and construction industries over 5000 years due to the certain and favorable properties such as durability, high strength and economic affordability [1] . Globally, day by day, as urbanization is drastically enhanced, a huge amount of bricks are extensively required [2], and thus demand of the bricks can be visually seen. Generally, in brick production, the raw clay is extracted, mixed with water then, moulded into various shapes and patterns in an extruder, dried under the sun to evaporate water, and fired in a kiln using combustible materials such as coconut shells, firewood, and waste etc. at a temperature above $900^{\circ} \mathrm{C}$.

However, the quality of bricks is still major concern in most part of the world because brick-makers heavily dependent on local techniques, unaware about firing temperature and quality of clay. Thus, they have not achieved proper density, degree of hardness and colour desired. Some cases, the same clay can yield different results when fired at different temperatures. Generally, vitrification is the process of forming glass-like material due to the binding of all the necessary elements with clay at and above $900^{\circ} \mathrm{C}$. When clay bricks are heated to a high temperature, series of chemical reactions occur in the clay, which make the brick permanently hard, durable, and resistant to weathering [3]. Therefore, the final quality of the brick depends mainly on the degree of vitrification.

The marketability of the bricks depends on numerous factors include aesthetics (colour, texture and shape), physical properties, price and availability [4,5]. Among these, colour is one of the most important and fundamental property which attract the consumer's attention. Because of this, now-a-days brick manufactures take advantage and produce reddish coloured bricks by adding some chemicals into raw clay material or changing the atmosphere of the kiln, and thus, quality of the bricks is deviated. Interestingly, quality of the bricks is also varied when the same coloured bricks are collected from the two parts of the kiln.

In Tamilnadu (state), India, bricks have been made in the kilns by heating with fire wood. In this process, heat generated at the centre spreads to all bricks from the centre to its peripheral areas. The bricks on the outer surface are mostly found to be halfburnt and unbaked as outer surface is insulated with a coat of clay. As well as, if the outer surface is damaged, heat is escaped, and thus, quantity of half-brunt and unbaked bricks are increased. Since they cannot be used for building materials, they are disposed as 


\section{International Journal of Current Science Research and Review}

ISSN: 2581-8341

Volume 05 Issue 01 January 2022

DOI: 10.47191/ijcsrr/V5-i1-26, Impact Factor: 5.825

IJCSRR@ 2022

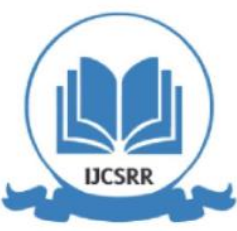

WwW.ijesrr.org

wastes which cause the environmental problem.

The present study has indented to study the mineralogy, temperature effect, firing temperature and mechanical behavior of the handmade brick collected from inner and outer parts of the traditional kiln by approaching refiring technology. The present study also aimed to get the relationship among the above said characteristics to understand the quality variations of the bricks.

\section{MATERIALS AND METHODS}

To study the quality of the bricks, raw clay material and twenty industrial brick materials ( 10 samples from inner part and 10 samples from outer part of the traditional kiln) were collected from Mangaimadam (11 $11^{\circ} 57.77^{\prime \prime N}$ and $79^{\circ} 47^{\prime} 55.86^{\prime \prime E}$ ) (Fig.1) located in Nagappattinam District, Tamilnadu (state), India. It is one of the important places for brick production in the state as one of the major rivers (Cauvery River) is running and terminated in the Nagappattinam district.

Collected industrial brick samples were re-fired in laboratory condition in the temperature range from 500 to $900{ }^{\circ} \mathrm{C}$ with the steps of $100{ }^{\circ} \mathrm{C}$ for two hours and allowed to cool

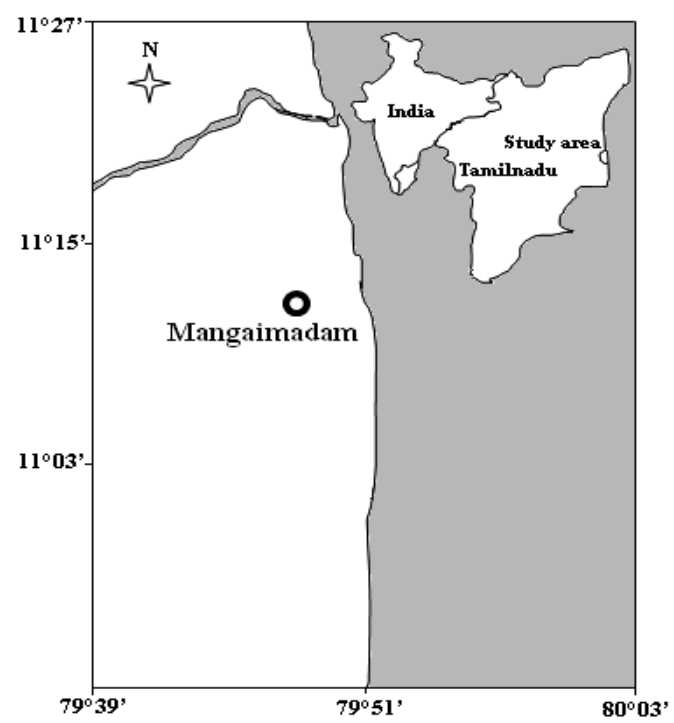

Fig. 1: The location Map of clay material and industrial clay bricks investigated (Mangaimadam).

In the furnace to room temperature. The samples were characterized by FTIR, XRD, XRF and mechanical property analyser. Details of the characterization techniques are as follows; FTIR spectra were recorded by Perkin-Elmer spectrometer (Model: Paragon 500) in the frequency region $4000-400 \mathrm{~cm}^{-1}$ using standard $\mathrm{KBr}$ pellet technique. The accuracy of the measurement is $\pm 4 \mathrm{~cm}^{-1}$.

The chemical composition of raw clay material was obtained by fluorescence spectrometry (Philips, PW 2400). The X-ray

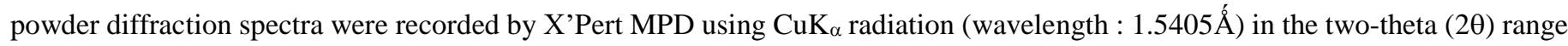
from 20 to $80^{\circ}$. The particle size distribution of raw clay material was determined by sieving and sedimentation method according to the Indian standard. The equivalent spherical diameter of the material is calculated using Stoke's law.

The plasticity of the raw clay material was determined by the Atterberg method, which gives the plastic limit, liquid limit and plastic index. The compressive strength is determined by dividing the maximum load with the applied load area of the brick samples. The flexural rupture strength of the samples is determined (Shimadzu Autograph-25A) by three point bending test of a constant cross speed of $0.5 \mathrm{~mm} / \mathrm{min}$. Water absorption, porosity and bulk density of the respective specimens were determined by using the Archimedes water displacement method.

\section{RESULTS AND DISCUSSION}

The chemical composition of the raw clay material (Table 1) shows the expected typical composition, it is rich in silica (60.75\%) and second rich in alumina (17.21\%) with minor contents such as $\mathrm{Mg}, \mathrm{Ca}, \mathrm{K}, \mathrm{Na}$ and $\mathrm{Mn}$ oxides, accompanied with significant 


\section{International Journal of Current Science Research and Review}

ISSN: 2581-8341

Volume 05 Issue 01 January 2022

DOI: 10.47191/ijcsrr/V5-i1-26, Impact Factor: 5.825

IJCSRR@ 2022

WWw.ijcsrr.org

amount of iron oxide content (4.37\%). The presence of significance amount of iron oxide content is responsible for reddish colour of the fired brick materials [6].

Table 1: Chemical composition of raw clay material (wt.\%).

\begin{tabular}{|l|l|}
\hline $\mathrm{Name}$ of the Chemical constituent & wt.\% \\
\hline $\mathrm{SiO}_{2}$ & 60.75 \\
\hline $\mathrm{Al}_{2} \mathrm{O}_{3}$ & 17.21 \\
\hline $\mathrm{Fe}_{2} \mathrm{O}_{3}$ & 5.37 \\
\hline $\mathrm{CaO}$ & 4.48 \\
\hline $\mathrm{MgO}$ & 2.48 \\
\hline $\mathrm{Na}_{2} \mathrm{O}$ & 1.68 \\
\hline $\mathrm{K}_{2} \mathrm{O}$ & 1.87 \\
\hline $\mathrm{MnO}$ & 0.32 \\
\hline $\mathrm{P}_{2} \mathrm{O}_{5}$ & 0.13 \\
\hline $\mathrm{TiO}_{2}$ & 0.25 \\
\hline $\mathrm{Loss}$ on ignition ( LoI) & 4.99 \\
\hline
\end{tabular}

The presence of significant amount of alkaline, alkaline - earth oxide content $\left(\mathrm{Na}_{2} \mathrm{O}, \mathrm{K}_{2} \mathrm{O}, \mathrm{CaO}\right.$ and $\left.\mathrm{MgO}\right)$ and iron oxide in the clay material promotes the liquid phase formation and develop the mechanical strength during firing at $900^{\circ} \mathrm{C}$ [7].The loss on ignition of the clay is $4.99 \%$ which is the below usual range of clay material. The loss on ignition is associated with volatile components and organic matter burn-off [8].

The particle size distribution of the raw clay material (Fig. 2) shows that the percentage of < $2 \mu \mathrm{m}$ (clay) particle in the clay minerals is $48 \%$. Silt is intermediate fraction $(2-20 \mu \mathrm{m})$ which is $23 \%$. Percentage of the fine sand $(20-200 \mu \mathrm{m})$ and coarser fraction $(>200 \mu \mathrm{m})$ in the clay material are $25 \%$ and $4 \%$ respectively. The presence of high content of clay $(48 \%)$ in the raw clay material is the responsible for its moderate plasticity [9] and exhibit the favorable mechanical property. Plasticity is an important parameter which is related to mechanical behavior of the clay bricks. Brick industry mainly uses extrusion shaping and therefore insufficient of plasticity creates extrusion failures and heterogeneities in clay body and these causes lower mechanical properties [10].

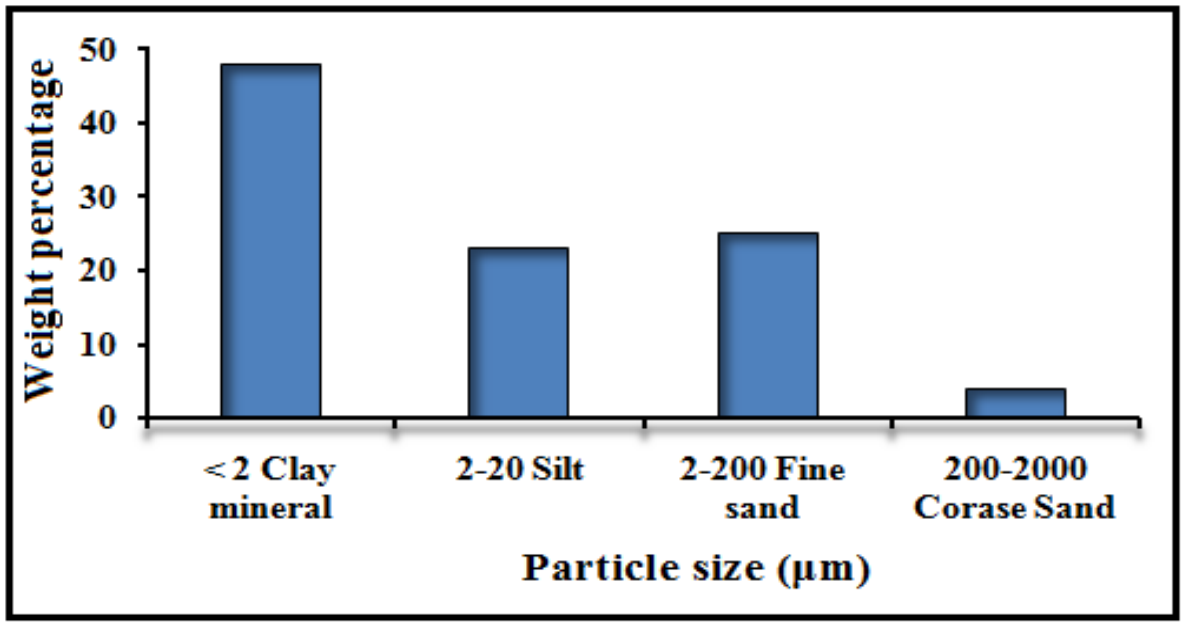

Fig. 2: Particle size distribution of the raw clay material.

Generally, the liquid limit is the relatively high water content at which the clay changes from a liquid to a plastic state, and the plasticity limit is the relatively low water content at which clay changes from a plastic to a solid state. Plasticity index refers to the resistant force to deformation and gives a better appraisal of the behaviour of plastic substance. According to Vieira et al. [11], for practical purposes the plasticity index must be above $10 \%$ and if it is $<10 \%$, are not appropriate for the production of clay-based 


\section{International Journal of Current Science Research and Review}

ISSN: 2581-8341

\section{Volume 05 Issue 01 January 2022}

DOI: 10.47191/ijcsrr/V5-i1-26, Impact Factor: 5.825

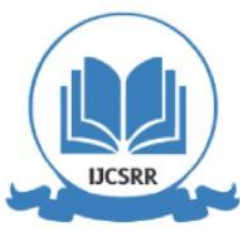

Www.ijcsrr.org

materials due to the risk of problems during the extrusion process. In the present work, the liquid limit, plasticity limit and plasticity index of the raw clay material are 44.2, 24.8 and $21.5 \%$ respectively. This indicates that the present clay material is well suited for the production of clay bricks in the industry.

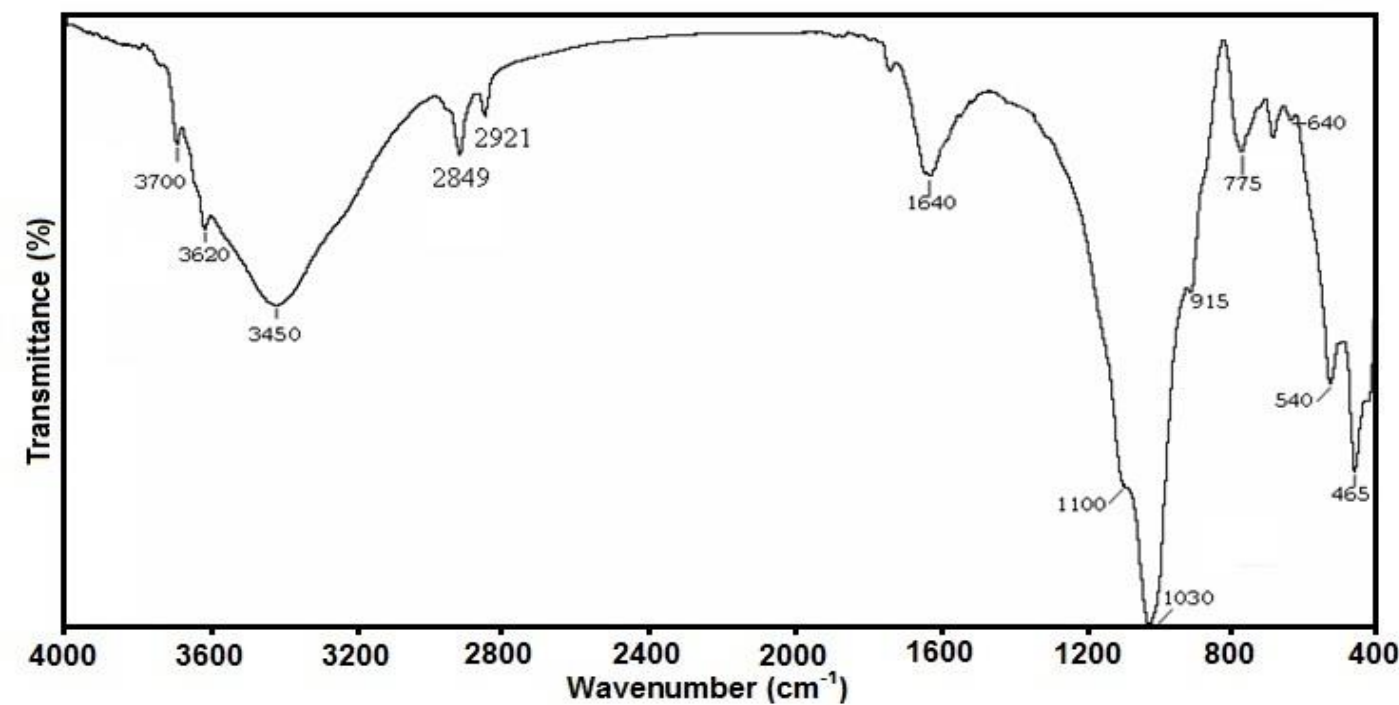

Fig. 3: Room temperature FT-IR absorption spectrum of raw clay material collected from Mangaimadam.

The magnitude of the thermal changes in clay body largely depend on the grain size, chemical and mineralogical compositions during the fabrication, besides temperature of exposure and its duration, fabric of clay mass and inter particle gets micro structural alterations $[12,13,14]$. These changes can be seen in the FTIR. Fig.3 shows the room temperature FT-IR spectrum of clay material. The bands observed at 3700 and $3620 \mathrm{~cm}^{-1}$ are due to presence of disordered Kaolinite [15]. A broad and very strong asymmetry band centered at $1030 \mathrm{~cm}^{-1}$ indicates that the type of clay is red [16]. The presence of weak band at $775 \mathrm{~cm}^{-1}$ coupled with $695 \mathrm{~cm}^{-1}$ is attributed to the presence of quartz [17,18]. The presence of sufficient amount of quartz makes the clay to be self-tempered. The very weak band observed at $640 \mathrm{~cm}^{-1}$ is attributed to Al-O co-ordination vibration. The band observed at $540 \mathrm{~cm}^{-1}$ is attributed to iron oxides probably due to $\mathrm{Fe}-\mathrm{OOH}$ (goethite). Strong band observed at $465 \mathrm{~cm}^{-1}$ is attributed to Si-O-Si bending mode. The bands at 3700, 3620, 1109, 915, 580 and 540 are sensitive to temperature effect, and acts as a thermometer in determining the firing temperature of any clay based materials. The bands at 795, 775, 695, 640, 465 and $430 \mathrm{~cm}^{-1}$ are always free from any temperature effects. The FTIR spectra of both inner and outer bricks are compared with the spectra obtained for the raw clay material to assess the type of clay, firing temperature and firing condition followed by the brick making people during its manufacture. The FT-IR spectra of inner and outer bricks (as received state (ARS)) and re-fired in laboratory condition at 500 to $900{ }^{\circ} \mathrm{C}$ are shown in Fig. 4 and 5. In both bricks samples, the absence of the bands at 3700 and $3620 \mathrm{~cm}^{-1}$ indicates that they have been fired above $450^{\circ} \mathrm{C}$. Wagner et al. [19] have reported that kaolinite disappears in between 400 and $450^{\circ}$ during firing process. The band at $915 \mathrm{~cm}^{-1}$ is due to $\mathrm{OH}$ deformation vibrational mode which arises from intrasheet of hydroxyls [20]. These are begun to disappear with increasing temperature ranging from 500 to $600{ }^{\circ} \mathrm{C}$. Because, at this temperature range the expandable layer of silicate structure of clay materials is usually collapsed resulting a broad and strong symmetry band centered at around $1030 \mathrm{~cm}^{-1}$ for red clay and $1080 \mathrm{~cm}^{-1}$ for white clay, respectively. The bricks collected from the outer part of the kiln show the characteristics band at $915 \mathrm{~cm}^{-1}$ in as received state and at refiring temperature $500^{\circ} \mathrm{C}$. This clearly implies that outer bricks must have been fired in-between 450 and $500^{\circ} \mathrm{C}$ during its manufacturing. The presence of iron oxides in clay materials is generally characterized by the existence of the band at $540 \mathrm{~cm}^{-1}$. On firing to higher temperatures, iron oxides are transformed into proto-hematite, hematite and magnetically ordered and well crystallized hematite $\left(\alpha-\mathrm{Fe}_{2} \mathrm{O}_{3}\right)$. These transformations can be studied from the variation in intensities of the bands at 540 and $580 \mathrm{~cm}^{-1}$.

To assess the original firing temperature of inner and outer bricks of Mangaimadam, re-firing methodology was also followed. No changes in the FTIR spectra are to be expected during laboratory re-firing of bricks until the re-firing temperature 


\section{International Journal of Current Science Research and Review}

ISSN: 2581-8341

Volume 05 Issue 01 January 2022

DOI: 10.47191/ijcsrr/V5-i1-26, Impact Factor: 5.825

IJCSRR@ 2022

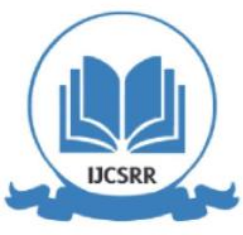

WWw.ijesrr.org

exceeds the original firing temperature. In this manner the maximum original firing temperature can be determined as the lowest re-firing temperature at which the FTIR spectra begin to change [21].

From Fig. 4, it can be seen that the FTIR spectrum of Mangaimadam inner brick in the as received state is the same as one obtained at the re-firing temperatures of $500,600,700$ and $800^{\circ} \mathrm{C}$. Increase in intensity of the band $580 \mathrm{~cm}^{-1}$ is noticed at $900^{\circ} \mathrm{C}$. The increase in intensity of the band $580 \mathrm{~cm}^{-1}$ at $900^{\circ} \mathrm{C}$ indicates that laboratory re-firing temperature exceeded the original firing temperature. From the above information it is concluded that the bricks collected from inner part of the kiln must be fired in between 800 and $900^{\circ} \mathrm{C}$

In the case of outer brick (Fig.5), it can be observed that the FTIR spectrum (as received state) is the same as obtained at $500{ }^{\circ} \mathrm{C}$ and $600{ }^{\circ} \mathrm{C}$. An increase in intensity of the band $\left(580 \mathrm{~cm}^{-1}\right)$ is noticed at 600 and $700{ }^{\circ} \mathrm{C}$, and further increase is observed at $800^{\circ} \mathrm{C}$ and $900^{\circ} \mathrm{C}$. Hence, it is concluded that the outer brick collected from the kiln must been fired at around $500^{\circ} \mathrm{C}$ during its manufacturing. As in the previous case the double let $\left(775\right.$ and $\left.695 \mathrm{~cm}^{-1}\right)$ is observed due to the presence of quartz. The bands observed at 3450 and $1640 \mathrm{~cm}^{-1}$ are attributed to $\mathrm{OH}$ stretching and $\mathrm{H}-\mathrm{O}-\mathrm{H}$ bending vibration of adsorbed water molecule [22]. Generally, on firing the clay or

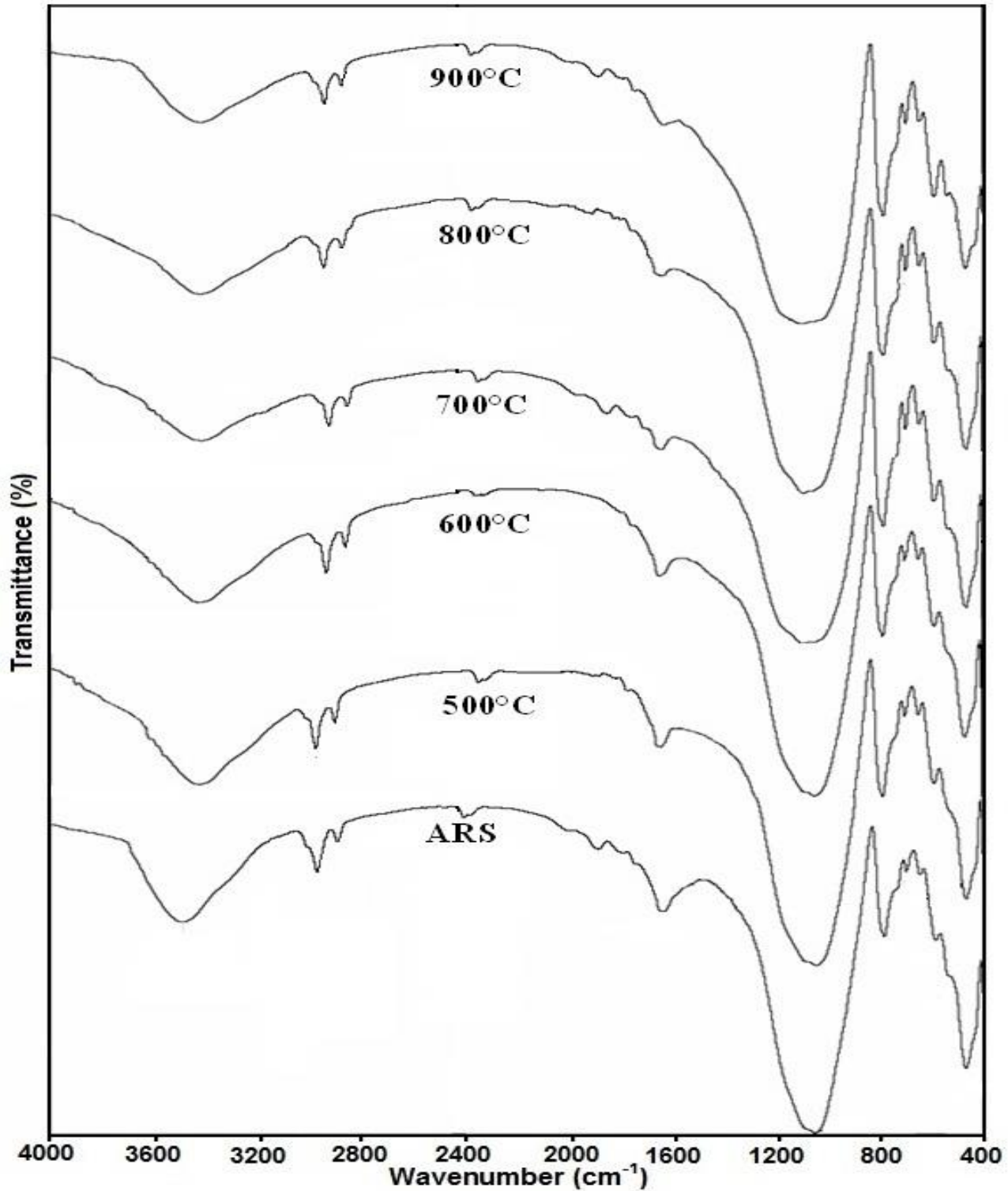

Fig. 4: FTIR absorption spectra of inner brick in the as received state and re-fired from $500^{\circ} \mathrm{C}$ to $900^{\circ} \mathrm{C}$ in the laboratory 
ISSN: 2581-8341

Volume 05 Issue 01 January 2022

DOI: 10.47191/ijcsrr/V5-i1-26, Impact Factor: 5.825

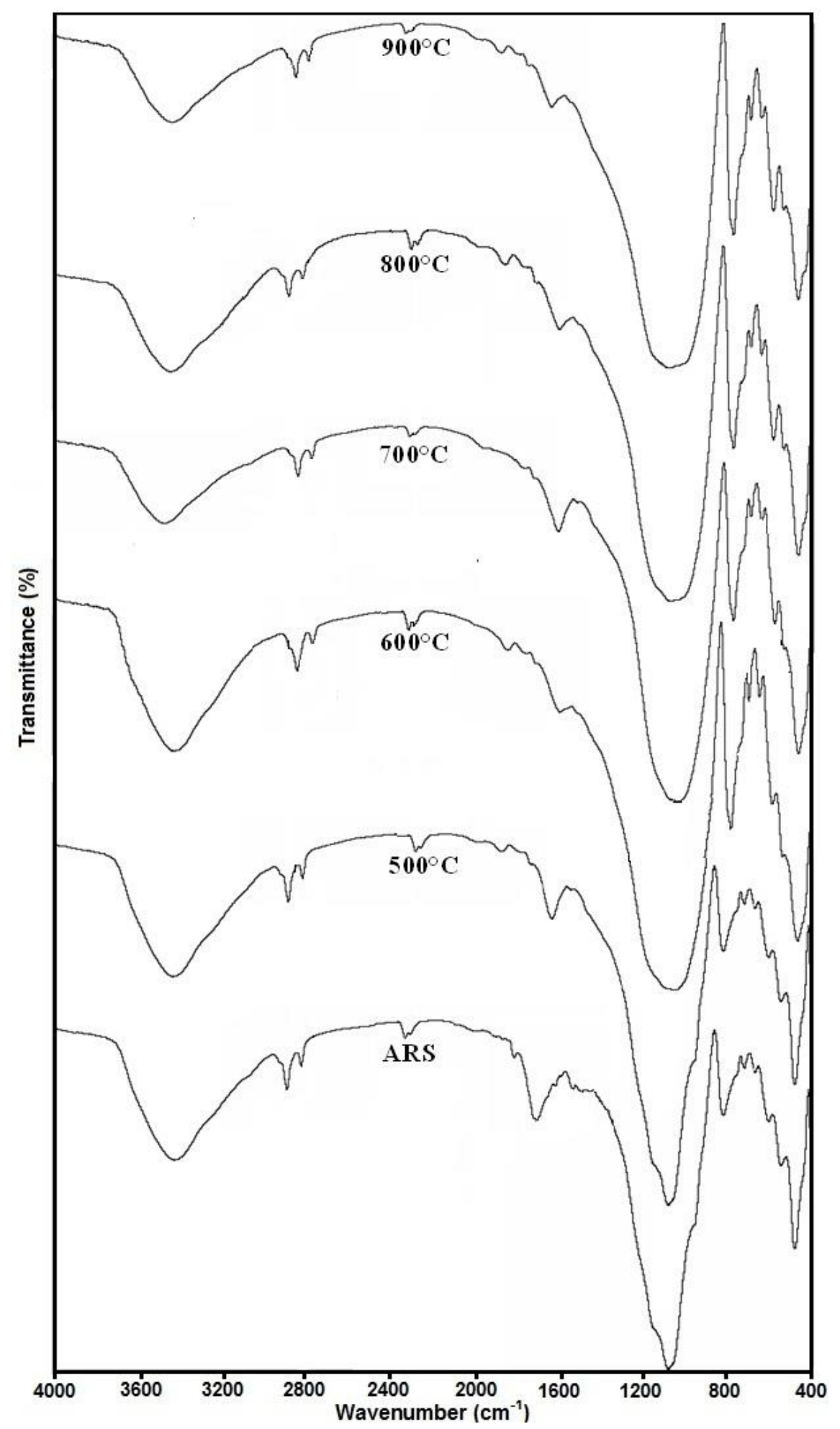

Fig. 5: FTIR absorption spectra of outer brick in the as received state and re-fired from $500^{\circ} \mathrm{C}$ to $900^{\circ} \mathrm{C}$ in the laboratory

Clay based materials to higher temperatures these bands will get diminished and disappear due to the evaporation of water molecules. In the present work, the existence of these bands up to $900^{\circ} \mathrm{C}$ might have been due to absorption of moisture in the 


\section{International Journal of Current Science Research and Review}

ISSN: 2581-8341

Volume 05 Issue 01 January 2022

DOI: 10.47191/ijesrr/V5-i1-26, Impact Factor: 5.825

IJCSRR@ 2022

WWW.ijcsrr.org

atmosphere by $\mathrm{KBr}$ while recording FTIR spectra [23].

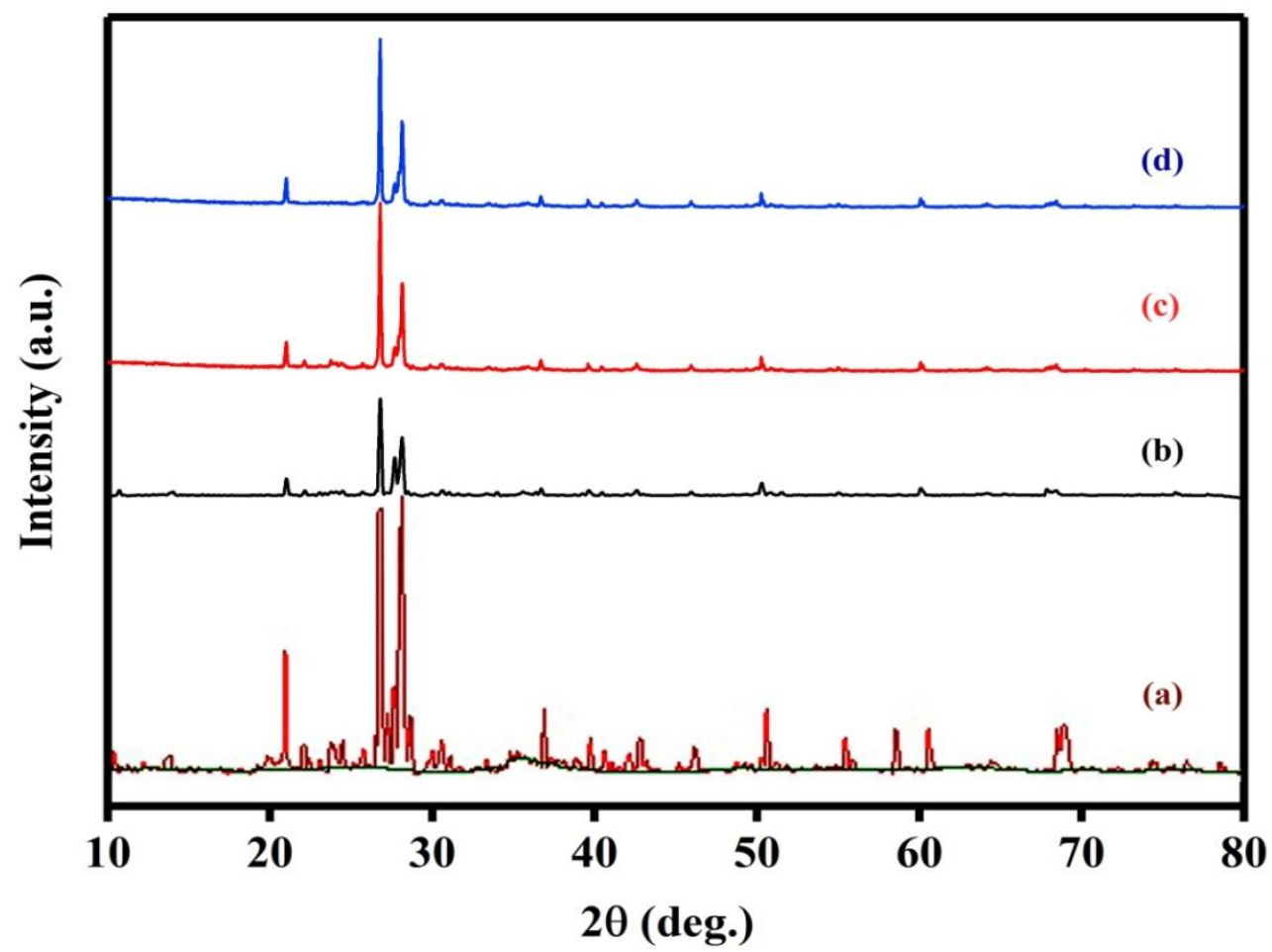

Fig.6: X-ray diffraction pattern of (a) Raw clay material (b) Outer brick (c) Inner brick (d) Outer brick re-fired at $900^{\circ} \mathrm{C}$ in the laboratory

Fig.6 represents the X-ray diffraction pattern of raw clay material at room temperature, inner brick, outer brick and the outer brick fired at $900^{\circ} \mathrm{C}$ in the laboratory. The presences of minerals were identified by comparing JCPDS (Joint Committee on Powder Diffraction Standards) file [24]. The peaks of the minerals which do not overlap are considered for identification. Quartz $(4.26,3.34,2.12$ and $1.181 \mathrm{~d} \AA)$ is the predominant mineral identified in all the materials, which makes the clay to be self-tempered during firing process. In addition, the above materials exhibit contributions of minor content of feldspar $(6.38$ 4.04, 4.02 and 3.18$3.19 \mathrm{~d} \AA$ ) and orthoclase. The presence of Kaolinite $(7.05,2.14$ and $1.55 \mathrm{~d} \AA$ ) was observed in the clay material and the bricks collected from the outer part of the kiln, however, the presence of iron oxides could not be detected because of its low concentration and poor crystallinity [25]. The results obtained through FTIR and XRD are in agreement with chemical analysis.

Fig. 7 represents the compressive and flexural rupture strength of industrial bricks collected from inner and outer part of a traditional kiln (as received state and function of re-firing temperatures in the laboratory). The compressive and flexural rupture strength tests are the most important tests that can be used to assure the engineering quality when it is used as building materials. The above parameters strongly depend on the porosity and microstructural defect of the bricks. From the results, it can be seen that the measured compressive and flexural rupture strengths of the bricks collected from inner part of kiln are higher than that of the bricks collected from the outer part of the same kiln. The above results reveal that firing temperature is one of the important factors for attaining the desired strengths in clay based materials.

Mechanical behavior of clay bricks such as compressive and flexural rupture strengths, water absorption, porosity and bulk density are inter-related. Water absorption, porosity and bulk density of different bricks collected from inner and outer part of a kiln (as received state and as a function of re-firing temperatures) are presented in Fig.7. The water absorption rate, which refers to the weight of the moisture in the pores compared to the sintered specimen's weight, is an effective index for evaluating the brick quality. The less water that infiltrates the brick makes to expect greater durability and resistance to the natural environment [26]. Hence the water absorption of bricks is measured to investigate the extent of densification in the fired body and also used as an expression to open pores [27]. 
ISSN: 2581-8341

Volume 05 Issue 01 January 2022

DOI: 10.47191/ijcsrr/V5-i1-26, Impact Factor: 5.825
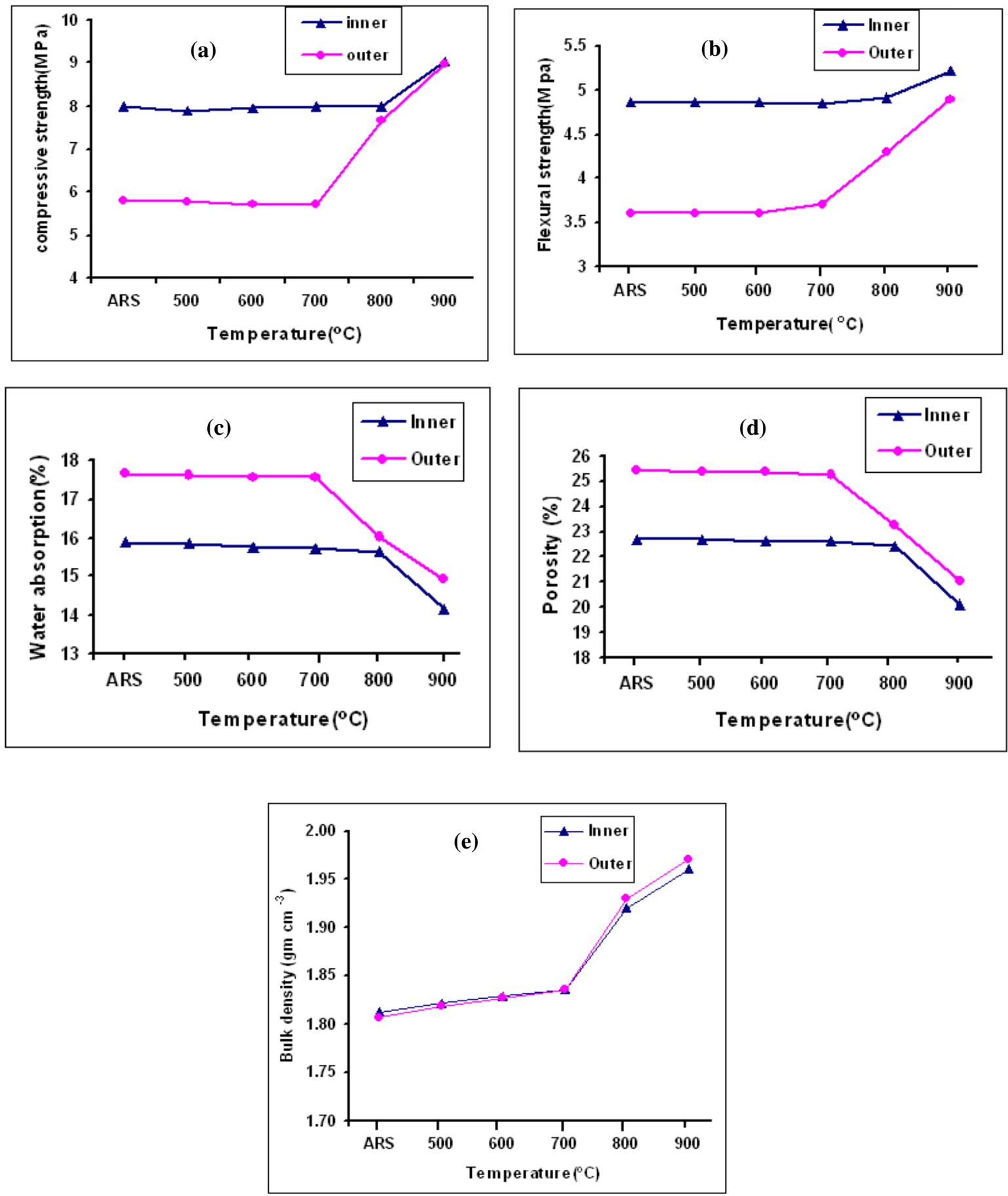

Fig. 7: Mechanical properties of inner and outer bricks collected from a traditional kiln located at Mangaimadam in the as received state and as a function of re- firing temperature (a) Compressive strength (b) Flexural rupture strength (c) Water absorption (d) porosity and (e) Bulk density.

In this work, the relationship between water absorption, porosity and bulk density of bricks collected from inner and outer part of a kiln have been studied. From the results of the above studies it is found that water absorption and porosity of both bricks 


\section{International Journal of Current Science Research and Review}

ISSN: 2581-8341

Volume 05 Issue 01 January 2022

DOI: 10.47191/ijcsrr/V5-i1-26, Impact Factor: 5.825

IJCSRR@ 2022

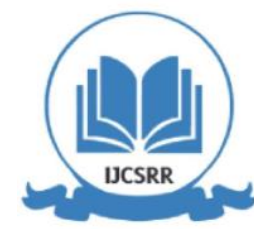

WWw.ijcsrr.org

inversely proportional to the re-firing temperature. Reduction in the water absorption and porosity and increase in bulk density of the bricks at higher temperatures clearly indicates that the decrease of cavity or pores in the brick materials and are due to different microstructure developed (especially, liquid phase formation of alkaline and alkaline-earth oxide contents) on brick materials during re-firing process in the laboratory.

The values of water absorption and porosity of the inner part of the bricks are lower than that of outer one .This reflects that the bricks collected from inner part of a kiln are more durable and better resistance against environmental damage. The bulk density measured for the above two different bricks satisfied the requirement reported in literature [26]. However, it is interesting to note that water absorption, porosity and bulk density measured for industrial brick materials collected from inner and outer part of a kiln (as received state and up to the re-firing temperatures) before exceeds its original firing temperature in the laboratory are almost consistent. When laboratory re-firing temperature exceed the original firing temperature of inner and outer part of the bricks, the water absorption and porosity values decreases and bulk density values increases significantly. This concludes that a study of mechanical behavior of clay-based materials helps to assess the original firing temperature of clay-based materials during its manufacturing. The changes in mechanical properties are observed when the re-firing temperature exceeds the original firing temperature. Similar type of changes in intensity of the band $\left(580 \mathrm{~cm}^{-1}\right)$ is observed in FTIR studies.

\section{CONCLUSION}

FTIR, XRD and mechanical studies were performed on fired industrial clay bricks collected from inner and outer parts of a traditional kiln. From the results, the following conclusions are drawn:

- $\quad$ From FTIR and mechanical studies, it is estimated that bricks collected from inner part of the kiln might have been fired in between 800 and $900^{\circ} \mathrm{C}$, whereas the outer bricks have been fired in between 500 and $600^{\circ} \mathrm{C}$ under oxidizing atmospheric conditions. The presence of hematite $\left(\alpha-\mathrm{Fe}_{2} \mathrm{CO}_{3}\right)$ and oxidizing atmospheric firing are the reasons for reddish colour of the brick materials.

- Quartz was found to be main mineral, makes the clay to be self-tempered during firing process. Minor amounts of plagioclase and orthoclase have also been identified.

- Results of mechanical studies showed that the quality of inner brick especially the strength is higher than that of outer one. The quality of bricks in the outer part of the kiln can be improved by increasing the thickness of the coat of clay of the kiln, so as to prevent the flow of heat to the atmosphere and for the uniform distribution of heat to the entire parts of the kiln. Hence, all the bricks produced in the kiln may be used for construction purposes, which will reduce the environmental problem such as the exhaustion of natural resources in the form half-burnt and unbaked bricks.

\section{Acknowledgement}

We are grateful to Mr. K. Saravanan, M.E., Assistant Technical Officer, Department of Structural Engineering, Faculty of Engineering and Technology (FEAT), Annamalai University, for his timely help in carrying out mechanical measurements. The authors are also thankful to HOD, Department of Chemistry, Annamalai University, Tamilnadu, India, for providing FTIR facility to carry out the present work.

\section{BIBLIOGRAPHY}

1. Monatshebe, T, Mulaba-Bafubiandi, A. F., \& Nyembwe, D. K. (2019). Mechanical properties and mineralogy of artisanal clay bricks manufactured in Dididi, Limpopo, South Africa. Construction and Building Materials, 225, 972-982.

2. Presertsan, S., \& Theppaya, T. (1995). A study towards energy saving in brick making, part I: Key parameters for energy saving ERIC International Energy Journal, 17(2), 145-156.

3. Murad, E., Wagner, U. (1998). Clays and Clay minerals: The firing process. Hyperfine Interactions, 117, $337-356$.

4. Cultrone, G., Sebastián, E., Elert, K., de la Torre, M.J., Cazalla, O., \& Navarro, C.R. (2004). Mineralogical and physical characterization of the bricks used in the construction of the "Triangul Bastion", Riga (Latvia). Journal of European Ceramic Society, 24(3), 547-564.

5. Coletti, C., Cultrone, G., Maritan, L., \& Mazzoli, C. (2016). How to face the new industrial challenge of compatible, sustainable brick production: study of various types of commercially available bricks. Applied Clay Science, 124, $219-226$. 


\section{International Journal of Current Science Research and Review}

ISSN: 2581-8341

Volume 05 Issue 01 January 2022

DOI: 10.47191/ijesrr/V5-i1-26, Impact Factor: 5.825

IJCSRR@ 2022

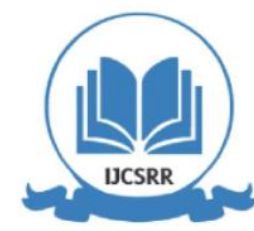

WWW.ijesrr.org

6. Segadaes, A.M., Carvalho, M.A., \& Acchar, W. (2005). Using marble and granite rejects to enhance the processing of clay products. Applied Clay Science, 30, 42-52.

7. Manoharan, C., Sutharsan, P., Dhanapandian, S., Venkatachalapathy, R., \& Mohamed Asanulla, R. Analysis of temperature effect on ceramic brick production from alluvial deposits, Tamilnadu, India. Applied Clay Science, 54, 20-25.

8. Dhanapandian, S. \& Gnanavel, B. (2009). Utilization of granite and marble sawing powder wastes as brick materials. Carpathian Journal of Earth and Environmental Sciences, 4(2), 147-160.

9. Manoharan, C., Sutharsan, P., Dhanapandian, S., \& Venkatachalapathy, R. (2012). Spectroscopic and thermal analysis of red clay for industrial applications from Tamilnadu, India. Journal of Molecular Structure, 1027, 99-103.

10. Demir, I., Baspinar, M., \& Orhan, M. (2005). Utilization of Kraft pulp production residues in clay brick production. Building and Environment, 40, 1533-1537.

11. Vieira, C.M.F. Sanchez, R., \& Monteiro, S.N. (2008). Characteristics of clays and properties of building ceramics in the state of Rio de Jeneiro, Brazil. Construction and Building Materials, 22, 781-787.

12. Brownell, W.E.(1976). Structural Clay Products, New York, Springer Verlag, pp.126-164.

13. Zerbo, L., Seynou1, M., Sorgho, B., Lecomte-Nana, G., Gomina, M., \& Blanchart, P. (2019). Microstructure and Weibull distribution of rupture strength of clay-talc ceramics. Cerâmica, 65, 240-245.

14. Conconi, M.S., Morosi, M., Maggi. J., Zalba, P.E., Cravero, F., \& Rendtorff, N.M. (2019). Thermal behavior (TG-DTATMA), sintering and properties of a kaolinitic clay from Buenos Aires Province, Argentina. Cerâmica, 65, 227.

15. Ramaswamy, K. \& Venkatachalapathy, R. (1992). Infrared spectroscopi analysis of sedimentary formations of Neyveli Lignite Mine Cut-II. Indian Journal of Pure and Applied Physics., 30, 171-175.

16. Ghosh, S.N. (1978). Infrared spectra of some selected minerals, rocks and products. Journal of Materials Science, 13, 18771886.

17. Ojima J. (2003). Determining of crystalline silica in Respirable Dust Samples by Infrared Spectrophotometry in the presence of Interferences. Journal of Occupational Health, 45, 94-103. Journal of Occupational Health, 45, 94.

18. Manoharan, C., Veeramuthu, K., Venkatachalapathy, R., Radhakrishnan, R. \& Ilango, R., (2008). Spectroscopic and ancient geomagnetic field intensity studies on archaeological pottery samples, India. Lithuanian Journal of Physics, 48(2), $195-202$.

19. Wagner, U., Gebhard, R., Hausler, W., Hutzelmann, T., Riederer, J., Shimada, I., Sosa, J. \& Wagner, F.E. (1999). Reducing firing of an early pottery making kiln of Batan Grande, Peru: A Mossbauer study. Hyperfine Interactions, 122, 163 -170.

20. Bantignies, J.L., Cartier dit Moulin, C., \& Dexpert, H. (1997). Wettability contrasts in Kaolinite and illite clays. Characterization by Infrared and X-ray absorption spectroscopies. Clays and Clay Minerals, 45(2), 184-193.

21. Wagner, U., Gebhard, R., Murad, E., Riederer, J., Shimada, I., Ulbert, C. \& Wagner, F.E. (1998). Production of Formative Ceramics: Assessment by Physical Methods, in : MASCA Research Papers in Science and Archaeology, Supplement to Vol. 15, University of Pennsulvania, Museum of Archaeology and Anthropology, Philadelphia, pp.173-197.

22. Wolff, R.G. (1965). Infrared absorption patterns (OH region) of several clay minerals. The merican Mineralogist, The American Mineralogist, 50, 240-244.

23. Manoharan, C., Sutharsan, P., Dhanapandian, S., Venkatachalapathy, R., 2012.Characteristics of some clay materials from Tamilnadu, India, and their possible ceramic uses. Cerâmica 58 , 412-418.

24. Mineral Powder Diffraction File, Joint Committee on Powder Diffraction Standards (JCPDS), 1999.

25. Wagner, U., Gebhard, R., Hausler, W., Hutzelmann, T., Riederer, J., Shimada, I., Sosa, J. \& Wagner, F.E., (1999). Reducing firing of an early pottery making kiln of Batan Grande, Peru: A Mossbauer study. Hyperfine Interactions, 122, $163-170$.

26. Lin, K.L . (2006). Feasibility study of using brick made from municipal solid waste incinerator fly ash slag. Journal of Hazardous Materials, B137, 1810-1816.

27. El-Mahllawy, M.S. (2008). Characteristics of acid resisting bricks made from quarry residues and waste steel slag. Construction and Building Materials, 22(8), 1887-1896.

Cite this Article: P. Sutharsan, S. Dhanapandian, V. Venkatachalam, T.M. Puratchi Mani, S. Abraham Rajasekar (2022). Handmade Traditional Kiln Clay Bricks from Tamilnadu, India: Mineralogy, Temperature Effect and Mechanical Analysis. International Journal of Current Science Research and Review, 5(1), 226-235 